\title{
Trade-offs between the short- and long-term effects of residue quality on soil $\mathbf{C}$ and $\mathbf{N}$ dynamics
}

\author{
Roberta Gentile • Bernard Vanlauwe • \\ Pauline Chivenge $\cdot$ Johan Six
}

Received: 28 October 2009 /Accepted: 19 March 2010/Published online: 13 April 2010

(C) The Author(s) 2010. This article is published with open access at Springerlink.com

\begin{abstract}
The decline of soil organic matter (SOM) and its associated fertility is one of the most important constraints to enhanced crop productivity in subSaharan Africa. Integrated soil fertility management recognizes the potential benefits of the combined use of organic residue and mineral fertilizer inputs for improved crop yield and SOM build up. However, these benefits may be controlled by residue quality. We examined the short- to long-term $\mathrm{C}$ and $\mathrm{N}$ dynamics following application of different quality residues with and without $\mathrm{N}$ fertilizer in a series of experiments comprising different timescales of measurement in a Kenyan Humic Nitisol. The combined results of these studies indicate that residue quality and fertilizer additions alter short-term $\mathrm{C}$ and $\mathrm{N}$ mineralization. Combining low quality residue and fertilizer inputs immobilized a greater amount of
\end{abstract}

Responsible Editor: M. Francesca Cotrufo.

R. Gentile $(\square)$

AgResearch, Private Bag 11008,

Palmerston North 4442, New Zealand

e-mail: roberta.gentile@agresearch.co.nz

B. Vanlauwe

TSBF-CIAT,

P.O. Box 30677, Nairobi, Kenya

R. Gentile $\cdot$ P. Chivenge $\cdot$ J. Six

Department of Plant Sciences, University of California, One Shields Ave.,

Davis, CA 95616, USA
fertilizer-N than high quality residue. Under field conditions, this reduction in available $\mathrm{N}$ induced by the combination of low quality residue and fertilizer reduced environmental $\mathrm{N}$ losses and created a positive interactive effect on crop $\mathrm{N}$ uptake. While input management manipulated short-term nutrient dynamics, it did not influence long-term SOM stabilization. The input of residue, regardless of quality, contributed to long-term soil fertility improvement. In conclusion, organic residue quality can be manipulated to optimize short-term nutrient dynamics while still conferring the same benefits to long-term SOM contents.

Keywords N fertilizer - Maize - Residue quality Soil organic carbon $\cdot$ Tithonia $\cdot$ Yield interactive effects

\section{Introduction}

Crop production in sub-Saharan Africa is constrained by the loss of soil organic matter (SOM) and its associated soil fertility decline (see Sanchez and Jama 2002). Thus, appropriate nutrient management strategies that both optimize in-season nutrient fluxes and build SOM reserves are critical for sustainable agriculture and poverty alleviation in the region. Addition of organic resources, such as animal manures and plant residues, promote SOM build-up and can improve long-term soil fertility. However, they may not be available in sufficient quantities to sustain production, especially since the majority are of a medium to low 
quality and thereby induce limited short-term nutrient availability (Palm et al. 2001; Vanlauwe and Giller 2006). Mineral fertilizers can address short-term nutrient deficiencies but do not contribute directly themselves to SOM build-up and long-term production. Additionally, they are not affordable in large quantities or widely available in proper formulations for smallholder farmers in Africa (Vanlauwe and Giller 2006). Thus an integrated approach is needed to optimize the application of all available resources and to maximize nutrient use efficiency and crop productivity in the short- and long-term.

The combined use of mineral fertilizers and organic residues is one of the main principles of integrated soil fertility management (ISFM) (Vanlauwe et al. 2009). Whereas neither input may be available in sufficient quantities to be used alone, their combined application may also generate interactive effects to improve timing of $\mathrm{N}$ availability, crop yields, and soil fertility in the long-term. While the application of readily available fertilizer will create high levels of available nutrients that exceed plant demand early in the season and can lead to potential nutrient losses, added organic residues may release nutrients too slowly during periods of plant demand possibly leading to nutrient deficiencies (Myers et al. 1994). Combining fertilizer with residue inputs may result in temporary immobilization and subsequent release of fertilizer-applied nutrients due to stimulation of microbial activity from the residue additions, thereby improving the synchrony between nutrient availability and crop demands (Vanlauwe et al. 2001b; Gentile et al. 2009). These interactions between input types may directly improve system nutrient use efficiency and reduce nutrient losses. The application of organic residues with fertilizers may also produce indirect interactive effects through the improvement of soil conditions (e.g. water holding capacity) that in turn improve plant growth and nutrient demand, which is met by fertilizer additions (Vanlauwe et al. 2001a; Vanlauwe et al. 2001b).

The potential interactive benefits of combining fertilizer and residue inputs are predicted to be controlled by residue quality (Vanlauwe et al. 2001b). As residue quality affects the rate of residue decomposition, quantity of $\mathrm{N}$ immobilization and timing of nutrient release (Heal et al. 1997), it will likely influence the interaction between fertilizer and residues. For example, in a lysimeter study, Vanlauwe et al. (2002) found that incorporating low quality (Zea mays L.) residue with $\mathrm{N}$ fertilizer reduced $\mathrm{N}$ leaching, but this effect was minor when fertilizer was combined with high quality Mucuna pruriens (L.) DC. residues.

Residue $\mathrm{N}$ concentration is the dominant parameter determining its quality due to the influence of $\mathrm{N}$ availability on microbial metabolism (Parton et al. 2007). Additionally, lignin and polyphenols have been identified as important quality parameters as lignin is one of the most recalcitrant $\mathrm{C}$ compounds and polyphenols can bind with proteins thereby immobilizing N (Melillo et al. 1982; Palm and Sanchez 1991). A synthesis of results from residue quality research led to the development of a conceptual classification system for organic residue management (Palm et al. 2001). This classification system incorporates data from nearly 300 plant species in tropical agroecosystems, divides residues into quality classes based on N, lignin and polyphenol contents, and recommends whether mineral fertilizer should be combined with the residues when they are applied. High quality residues (Class I) have $>2.5 \% \mathrm{~N},<15 \%$ lignin and $<4 \%$ polyphenol contents, and should be directly incorporated into soil. Medium quality residues are either Class II with $>2.5 \% \mathrm{~N},>15 \%$ lignin and $>4 \%$ polyphenols, or Class III with $<2.5 \% \mathrm{~N}$ and $<15 \%$ lignin contents. It is recommended that these medium quality residues should be applied in combination with mineral fertilizer. Low quality residues are Class IV with $<2.5 \% \mathrm{~N}$ and $>15 \%$ lignin contents and should only be surface applied to soil. Vanlauwe et al. (2005) validated this classification system with a 28-day soil incubation and found that Class I residues resulted in net $\mathrm{N}$ mineralization, Class II residues produced no change in mineral $\mathrm{N}$, and Class III and IV residues showed net $\mathrm{N}$ immobilization.

While there is much evidence that residue quality controls short-term $\mathrm{C}$ and $\mathrm{N}$ dynamics, the influence of residue quality and fertilizer additions, especially in combination, on medium- to long-term SOM stabilization is largely unknown. Soil organic matter is stabilized through biochemical, physical, and chemical stabilization mechanisms (Six et al. 2002; von Lützow et al. 2006). There is increasing evidence that intrinsic biochemical recalcitrance of residues does not contribute to long-term SOM stabilization (Gleixner et al. 2002; Kiem and Kögel-Knabner 2003). Therefore, SOM may not be stabilized in the long-term if it is not protected by physical mechanisms against micro- 
bial utilization (Marschner et al. 2008). Soil aggregates physically protect soil organic matter (Tisdall and Oades 1982) and influence microbial community composition (Mummey et al. 2006), thus their dynamics may play an important role in SOM stabilization. Since high quality residues and $\mathrm{N}$ fertilizer are postulated to increase aggregate turnover (Harris et al. 1963; Six et al. 2001), interactions between residue and fertilizer inputs may influence physical SOM stabilization.

Here we provide a synthesis of a series of studies, which allows us to consider the trade-offs between nutrient availability and stabilization induced by combining mineral fertilizer with organic residues of different quality. Combining the results of mineral $\mathrm{N}$ dynamics from laboratory and field experiments (Gentile et al. 2008a; Gentile et al. 2009), long-term crop yields (Chivenge et al. 2009) and field SOM stabilization (Gentile et al. 2008b), establishes novel and integrated conclusions on the benefits of ISFM. These previous studies looked at a variety of organic residue qualities, but this paper focuses on the comparison of high versus low quality residues in order to elucidate general principles. Class I and III quality residues based on the classification system of Palm et al. (2001) were selected to cover the range of available resources in sub-Saharan Africa and the variation in $\mathrm{N}$ mineralization rates (Vanlauwe et al. 2005). Class IV residues were not included as these are recommended to be surface applied and thus tillage would be a confounding factor within the treatments. Our objectives were to evaluate the influence of residue quality on the interactive effect of combining residue and fertilizer inputs on shortterm $\mathrm{N}$ availability, crop yield and long-term SOM formation. We hypothesized that lower quality residues would (i) increase the interactive benefits of combining inputs through improved $\mathrm{N}$ synchrony and (ii) enhance SOM stabilization.

\section{Materials and methods}

The effect of residue quality in combination with $\mathrm{N}$ fertilizer on short- to long-term nutrient dynamics was investigated in a series of lab and field experiments comprising different levels of environmental control and different timescales of measurement. The study site was at Embu, Kenya $\left(0^{\circ} 30^{\prime} \mathrm{S}, 37^{\circ} 27^{\prime} \mathrm{E}\right.$;
$1,380 \mathrm{~m}$ a.s.1.), which has a mean annual temperature of $20^{\circ} \mathrm{C}$. Mean annual rainfall is $1,200 \mathrm{~mm}$ and occurs in two distinct periods from March to June (long rains) and October to December (short rains), leading to two growing seasons within a year. The soil is a red clay Humic Nitisol (FAO 1998) dominated by kaolinite minerals. The texture of the surface soil $(0-15 \mathrm{~cm})$ is $17 \%$ sand, $18 \%$ silt, and $65 \%$ clay. At the start of the experiments the surface soil contained $29.3 \mathrm{~g} \mathrm{~kg}^{-1}$ organic $\mathrm{C}$ and $2.8 \mathrm{~g} \mathrm{~kg}^{-1}$ total $\mathrm{N}$. The organic residues used were tithonia [Tithonia diversifolia (Hemsl.) A. Gray], representing a high quality (Class I) residue and maize stover, representing a medium to low (Class III) quality residue. Tithonia is a shrub in the Asteraceae family and is found growing along farm borders and roadsides in many humid and sub-humid regions of subSaharan Africa. The high nutrient concentrations of tithonia biomass have led to interest in its use for soil fertility improvement (Jama et al. 2000).

Microcosm experiment

A laboratory microcosm experiment was used to trace the fate of input-applied $\mathrm{N}$ and $\mathrm{C}$ under controlled environment conditions. Full details of the experimental setup are given in Gentile et al. (2008a). Briefly, soil was collected from the field site in March 2002, sieved through $8 \mathrm{~mm}$ and air-dried. Plants of maize and tithonia were grown in the greenhouse and pulse-labeled with ${ }^{13} \mathrm{CO}_{2}$ according to the procedure of Bird et al. (2003). Additionally, a portion of the plants received ${ }^{15} \mathrm{~N}$-labelled fertilizer while the remainder was fertilized with unlabelled $\mathrm{N}$ solution. The plants were harvested after 2 months, oven-dried at $40^{\circ} \mathrm{C}$, and cut into $2-$ to $8-\mathrm{mm}$ sized residues. Residue quality parameters are given in Table 1 . Mineral N fertilizer and residue inputs were applied to $200-\mathrm{g}$ soil in a factorial design with four replicates per sampling time (3 months and $1.5 \mathrm{yr}$ ). Treatments included a no-input control, $\mathrm{N}$ fertilizer addition, residue addition, and residue combined with $\mathrm{N}$ fertilizer. For the $\mathrm{N}$ fertilizer treatment, the fertilizer was ${ }^{15} \mathrm{~N}$-labelled $(60$ atom\%). For the residue treatment, the ${ }^{15} \mathrm{~N}$-labelled residues were applied. For the combined input treatment, both the combinations of ${ }^{15} \mathrm{~N}$-labelled residue with unlabelled fertilizer and unlabelled residue with ${ }^{15} \mathrm{~N}$-labelled fertilizer were replicated four times to trace the fate of $\mathrm{N}$ 
Table 1 Residue quality characteristics for the microcosm and field trial

\begin{tabular}{|c|c|c|c|c|c|c|}
\hline Residue & $\mathrm{C}(\%)$ & ${ }^{13}$ C-enrichment (\%o) & N (\%) & ${ }^{15} \mathrm{~N}$-enrichment (atom \%) & Lignin $(\%)$ & Polyphenols (\%) \\
\hline \multicolumn{7}{|l|}{ Microcosm } \\
\hline Maize (unlabelled N) & $42 \pm 1$ & $1,047 \pm 62$ & $1.3 \pm 0.1$ & $0.4 \pm 0.0$ & 3.1 & 1.1 \\
\hline Maize ( ${ }^{15} \mathrm{~N}$-labelled) & $42 \pm 1$ & $1,714 \pm 103$ & $1.1 \pm 0.1$ & $40.0 \pm 0.6$ & 3.1 & 1.0 \\
\hline Tithonia (unlabelled N) & $38 \pm 1$ & $1,303 \pm 29$ & $3.2 \pm 0.2$ & $0.4 \pm 0.0$ & 4.4 & 2.5 \\
\hline Tithonia $\left({ }^{15} \mathrm{~N}\right.$-labelled $)$ & $43 \pm 1$ & $1,524 \pm 52$ & $2.8 \pm 0.1$ & $39.0 \pm 0.8$ & 4.4 & 2.2 \\
\hline \multicolumn{7}{|l|}{ Field Trial } \\
\hline Maize & $40 \pm 1$ & - & $0.7 \pm 0.1$ & - & $5.4 \pm 1.2$ & $1.2 \pm 0.2$ \\
\hline Tithonia & $38 \pm 1$ & - & $3.1 \pm 0.4$ & - & $8.9 \pm 0.8$ & $1.7 \pm 0.8$ \\
\hline
\end{tabular}

Values are means \pm SE. Lignin and polyphenol analyses on the microcosm residues were not replicated due to small sample size

derived from each input source. Residues were mixed into the dry soil at a rate of $3.65 \mathrm{~g} \mathrm{C} \mathrm{kg}^{-1}$ soil, equivalent to $4 \mathrm{Mg} \mathrm{C} \mathrm{ha}{ }^{-1}$. At this rate, 0.10 and $0.26 \mathrm{~g} \mathrm{~N} \mathrm{~kg}^{-1}$ soil was added with the maize and tithonia residue, respectively. Mineral $\mathrm{N}$ fertilizer was applied as urea $\left[\left(\mathrm{NH}_{2}\right)_{2} \mathrm{CO}\right]$ solution at a rate of $0.10 \mathrm{~g} \mathrm{~N} \mathrm{~kg}^{-1}$ soil, equivalent to $120 \mathrm{~kg} \mathrm{~N} \mathrm{ha}^{-1}$. The soils were maintained at 55\% WHC and incubated at $25^{\circ} \mathrm{C}$ in a controlled temperature room.

Extractable mineral $\mathrm{N}$ was measured at the 3 months sampling time to assess treatment effects on short-term $\mathrm{N}$ dynamics. Moist, 15-g subsamples were extracted with $75 \mathrm{ml} 0.5 \mathrm{M} \mathrm{K}_{2} \mathrm{SO}_{4}$. Mineral $\mathrm{N}$ concentrations were determined colorimetrically (Forster 1995; Doane and Horwath 2003) and the ${ }^{15} \mathrm{~N}$ isotopic signature of the extractable $\mathrm{N}$ was measured with a PDZ Europa isotope ratio mass spectrometer (Crewe, United Kingdom) following diffusion onto acidified disks (Stark and Hart 1996).

Soils from both sampling times were analyzed for residue-derived soil $\mathrm{C}$ to evaluate short- to long- term residue quality effects on SOM stabilization. Soil was air-dried, sieved through $2 \mathrm{~mm}$ to remove residue that was not incorporated in the SOM pool $(<2 \mathrm{~mm})$, ground, and analyzed for $\mathrm{C}$ and ${ }^{13} \mathrm{C}$ isotopic enrichment with a $\mathrm{PDZ}$ Europa isotope ratio mass spectrometer.

Field trial

A field trial was initiated in March 2002 as a long-term trial to evaluate the repeated application of different quality residues alone and in combination with $\mathrm{N}$ fertilizer on SOM dynamics. The experimental design was a split-plot with the organic residue input as the main plot and $\mathrm{N}$ fertilizer application as the subplot with three replicate blocks. The organic residue treatments included a control plot with no inputs and inputs of maize and tithonia residues, which were applied annually at the start of the long rains season at two

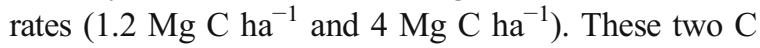
input rates contributed 20 and $70 \mathrm{~kg} \mathrm{~N} \mathrm{ha}^{-1}$ for maize and 90 and $300 \mathrm{~kg} \mathrm{~N} \mathrm{ha}^{-1}$ for tithonia residue, respectively. $\mathrm{N}$ fertilizer was applied at rates of 0 or $120 \mathrm{~kg} \mathrm{~N} \mathrm{ha}^{-1}$ season $^{-1}$ in a split application 4 and 8 weeks after planting, and maize was grown consecutively each growing season. Details of the full treatment structure and trial management have been previously reported (Chivenge et al. 2009; Gentile et al. 2009). Mean quality parameters for the residues applied in the field are listed in Table 1.

Crop yield was measured each growing season from 2002 to 2006 to determine the interactive effects of combining inputs on crop production (Chivenge et al. 2009). Additionally, short-term $\mathrm{N}$ dynamics were assessed during the 2007 long rains growing season in the $1.2 \mathrm{C} \mathrm{ha}^{-1}$ residue plots (Gentile et al. 2009). The low residue application rate was chosen for yield and mineral $\mathrm{N}$ comparisons to avoid excessive nutrient addition. Mineral $\mathrm{N}$ in the soil profile was determined by sampling 11 days before planting $(-11)$ and 15,29 , 49,83 , and 169 days after planting (DAP) to a depth of $150 \mathrm{~cm}$ in $30-\mathrm{cm}$ increments. Field-moist $20 \mathrm{-g}$ subsamples were extracted with $100 \mathrm{ml}$ of $2 \mathrm{M} \mathrm{KCl}$ and mineral $\mathrm{N}$ concentrations were determined colorimetrically as in the microcosm experiment. Soil bulk density measurements for each depth increment were used to express mineral $\mathrm{N}$ values on an area basis. Plant biomass samples were collected at harvest (168 DAP) for yield measurement. Grain subsamples were ground and analyzed for $\mathrm{N}$ content. 
In addition to the observations of crop production and in-season $\mathrm{N}$ dynamics, the effects of input treatments on long-term SOM stabilization were measured in the field trial. In March 2005, soil samples $(0-15 \mathrm{~cm})$ were collected from plots with the $4 \mathrm{Mg} \mathrm{C} \mathrm{ha}{ }^{-1}$ residue amendment. The high residue application rate was chosen for soil organic $\mathrm{C}$ analyses in order to observe treatment differences in plots with maximum residue contributions to soil $\mathrm{C}$. These samples were air-dried, 2-mm sieved, ground and analyzed for $\mathrm{C}$ contents.

Calculations and statistical analyses

The interactive effect of combining input types on maize yield and crop $\mathrm{N}$ uptake was calculated for each residue quality according to the equation of Vanlauwe et al. (2001b):

Interactive effect $=\mathrm{Y}_{\mathrm{R}+\mathrm{F}}-\mathrm{Y}_{\text {con }}-\left(\mathrm{Y}_{\mathrm{F}}-\mathrm{Y}_{\text {con }}\right)-$

$$
\left(\mathrm{Y}_{\mathrm{R}}-\mathrm{Y}_{\text {con }}\right)
$$

where $Y_{R+F}, Y_{\text {con }}, Y_{F}$ and $Y_{R}$ are the mean measured variables for the residue + fertilizer, control, fertilizer, and residue treatments, respectively. A significant positive interactive effect indicates that combining inputs stimulated crop production beyond what would have been expected from the sum of each added individually, and a negative interactive effect would imply a yield reduction. A non-significant interactive effect shows that the crop responded in an additive way when combining fertilizer and residue inputs.

Analyses of variance were performed on all measured variables using Proc MIXED in the SAS statistical software (SAS Institute, Cary, NC). Data from the microcosm experiment were analyzed as a complete randomized design, and data from the field trial were analyzed as a split-plot experiment. Treatment effects were deemed significant at $P<0.05$, and means were subsequently separated using the PDIFF option of the LSMEANS statement.

\section{Results}

$\mathrm{N}$ availability

Residue quality altered the mineral $\mathrm{N}$ pool after 3 months incubation in the microcosm trial (Fig. 1).
Residue-derived $\mathrm{N}$ values were $142 \mathrm{mg} \mathrm{N} \mathrm{kg}^{-1}$ soil lower with maize than tithonia in the residue alone treatments. While less $\mathrm{N}$ was added with the lower quality residue, maize also showed lower $\mathrm{N}$ release as the amounts of residue-derived $\mathrm{N}$ in the mineral pool accounted for only $34 \%$ of the added maize- $\mathrm{N}$ versus $71 \%$ of the added tithonia-N. Combining residue and fertilizer inputs both stimulated the release of residuederived $\mathrm{N}$ and immobilized fertilizer-derived $\mathrm{N}$. The addition of fertilizer increased the amount of residuederived mineral $\mathrm{N}$ by $53 \mathrm{mg} \mathrm{N} \mathrm{kg}^{-1}$ soil for tithonia while the amount of maize-derived $\mathrm{N}$ was not significantly affected. Conversely, the amount of fertilizer-derived mineral $\mathrm{N}$ decreased in the combination treatments. While all of the fertilizer-N was recovered in the mineral pool of the fertilizer alone treatment, this was reduced by $41 \mathrm{mg} \mathrm{N} \mathrm{kg}^{-1}$ soil when combined with maize and $27 \mathrm{mg} \mathrm{N} \mathrm{kg}^{-1}$ soil with tithonia. The combined input treatments did not alter the amount of soil-derived $\mathrm{N}$ in the mineral pool as compared to the control.

Similar treatment controls on short-term mineral N dynamics were observed during the 2007 long rains growing season in the field. Soil mineral $\mathrm{N}$ in the upper $60 \mathrm{~cm}$ of the soil profile, which contains $85 \%$ of root growth (Mugendi et al. 2003), displayed distinct treatment interactions with time (Fig. 2). The fertilized treatments had greater mineral $\mathrm{N}$ at all sampling dates throughout the season, which can be attributed to residual $\mathrm{N}$ from long-term mineral $\mathrm{N}$ application. However, changes in the residue effect and residue $\times$ fertilizer interaction at different sampling dates reveal different patterns of $\mathrm{N}$ release and immobilization between the residue qualities within the growing season. The tithonia residue resulted in early net mineralization and increased soil mineral $\mathrm{N}$ at 29 DAP by an average of $36 \mathrm{~kg} \mathrm{~N}^{-1}$ over the other treatments. Following the first fertilizer application, a significant residue quality $\times$ fertilizer interaction was observed at 49 DAP. Namely, combining fertilizer with maize residue decreased mineral $\mathrm{N}$ in comparison to the other fertilized treatments, resulting in a net $\mathrm{N}$ immobilization of $53 \mathrm{~kg} \mathrm{~N} \mathrm{ha}^{-1}$ on average. In contrast, the tithonia + fertilizer treatment did not alter mineral $\mathrm{N}$ compared to the fertilized control. By the time of flowering at 83 DAP, treatments showed depletion in soil mineral $\mathrm{N}$ and all residue quality effects had disappeared. For the remainder of the growing season, levels of mineral 


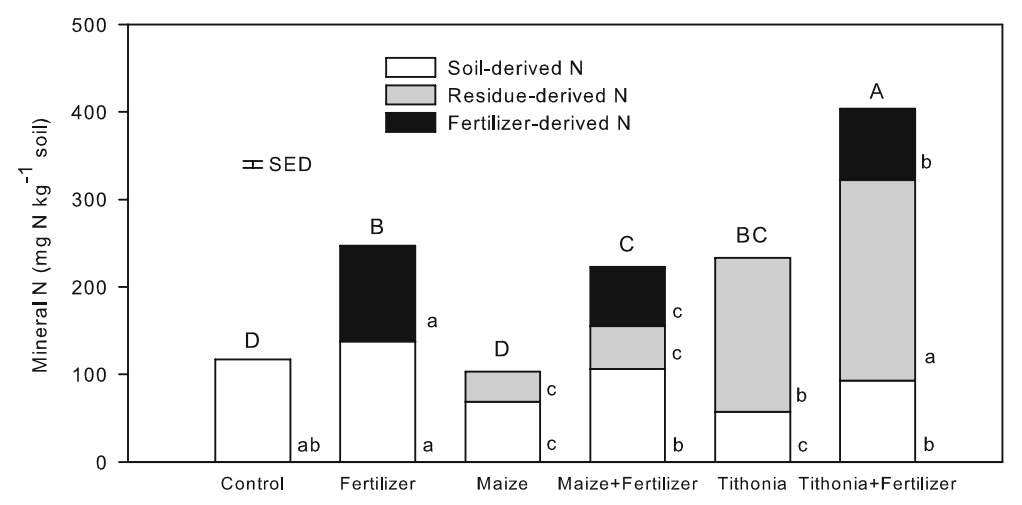

Fig. 1 Soil mineral $\mathrm{N}$ in the microcosm experiment after 3 months incubation following the application of different quality residues $\left(3.65 \mathrm{~g} \mathrm{C} \mathrm{kg}^{-1}\right.$ soil) with and without $\mathrm{N}$ fertilizer (100 mg N kg${ }^{-1}$ soil). Total mineral $\mathrm{N}$ is divided into its $\mathrm{N}$-source components according to soil-, residue- and fertilizer-derived N. Capital letters indicate significant treatment differences in total mineral $\mathrm{N}$ at $P<0.05$. Different lowercase letters within a $\mathrm{N}$-source indicate significant treatment differences at $P<0.05$ (data adapted from Gentile et al. 2008a)

$\mathrm{N}$ content regardless of its combination with residues. The treatment differences for this season mirror the mean yields of the previous 2002-2006 long rains seasons (Table 2).

Though residue addition did not influence overall yields, residue quality affected the interactive effect of combining input types (Table 2). For the 2007 long rains growing season, maize showed a trend $(P=0.06)$ for a positive grain $\mathrm{N}$ interactive effect of $9.5 \mathrm{~kg} \mathrm{~N} \mathrm{ha}^{-1}$ and no significant yield interactive effect. In contrast, tithonia had negative interactive effects for grain $\mathrm{N}$ and yield. Yield interactive effects calculated for the mean yields of the 2002-2006 long rains seasons reveal the same residue quality influence. Combining fertilizer with maize produced a trend $(P=$ $0.10)$ for a positive yield interactive effect of $0.50 \mathrm{Mg} \mathrm{ha}^{-1}$ while combination with tithonia had a negative interactive effect of $-0.74 \mathrm{Mg} \mathrm{ha}^{-1}$.
Fig. 2 Soil mineral $\mathrm{N}$ in the upper $0-60 \mathrm{~cm}$ at -11 , $15,29,49,83$ and 169 DAP during the 2007 long rains growing season following the application of different quality residues $(1.2 \mathrm{Mg} \mathrm{C}$ $\mathrm{ha}^{-1}$ ) with and without $\mathrm{N}$ fertilizer $\left(120 \mathrm{~kg} \mathrm{~N}^{-1}\right)$ (data adapted from Gentile et al. 2009)

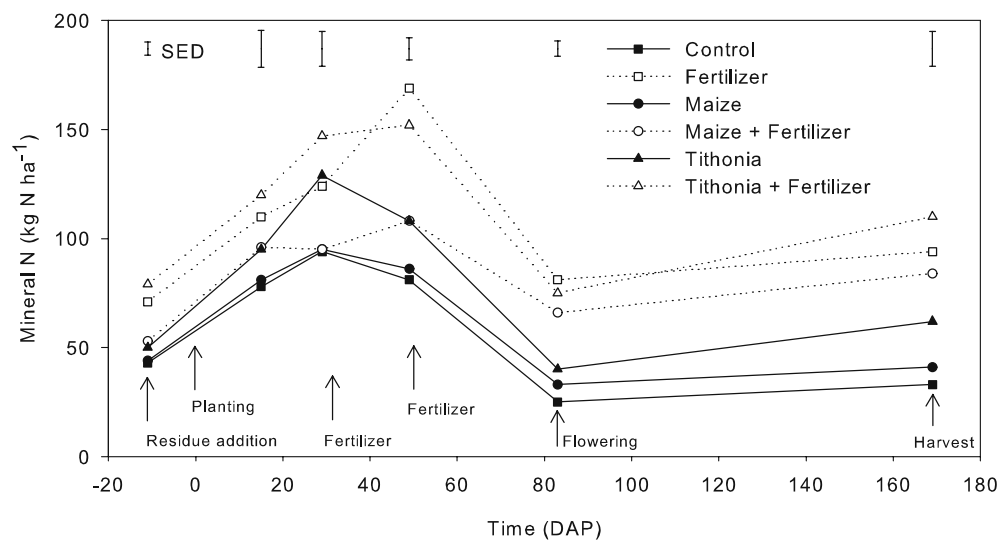




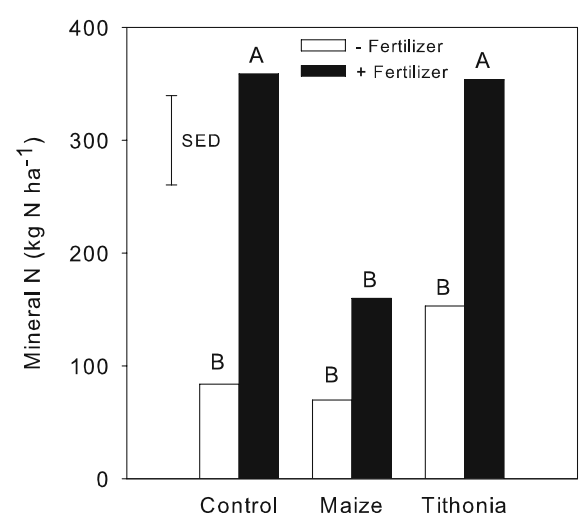

Fig. 3 Mean soil mineral $\mathrm{N}$ in the $60-150 \mathrm{~cm}$ subsoil for all sampling times during the 2007 long rains growing season following the application of different quality residues $(1.2 \mathrm{Mg}$ $\mathrm{C} \mathrm{ha}^{-1}$ ) with and without $\mathrm{N}$ fertilizer $\left(120 \mathrm{~kg} \mathrm{~N} \mathrm{ha}^{-1}\right)$. Different letters indicate significant treatment differences at $P<0.05$ (data adapted from Gentile et al. 2009)

\section{Soil organic carbon}

In the soil microcosm experiment, there was a significant residue quality $\mathrm{x}$ time interaction for the amount of residue-derived $\mathrm{C}$ stabilized in the soil. After 3 months of incubation, the high quality tithonia residue led to rapid decomposition, resulting in $0.33 \mathrm{~g}$ residue-derived $\mathrm{C} \mathrm{kg}^{-1}$ soil greater soil $\mathrm{C}$ than the maize residue (Fig. 4). However, after $1.5 \mathrm{yr}$ when all of the residue had decomposed, there were equivalent amounts of residue-derived $\mathrm{C}$ stabilized in the soils amended with the two different residue qualities. This lack of residue quality influence on longer-term soil C stabilization was mirrored in the field trial where three annual applications of residue increased soil organic
$\mathrm{C}$ compared to the no input control by an average of $5.85 \mathrm{~g} \mathrm{C} \mathrm{kg}^{-1}$ soil, but there were no differences in soil $\mathrm{C}$ between the two residue qualities (Fig. 5). The addition of $\mathrm{N}$ fertilizer also did not significantly affect soil $\mathrm{C}$ stabilization in either the microcosm or field trial.

\section{Discussion}

Soil fertility constraints in sub-Saharan Africa require integrated solutions that simultaneously address shortterm crop nutrient demands and long-term SOM enhancement (Sanchez and Jama 2002; Vanlauwe and Giller 2006). This unique synthesis of previously published data permits a comprehensive evaluation of the influence of residue quality on the interactive effects of combining residue and fertilizer inputs. The microcosm experiment used isotope tracers to examine short- to medium-term $\mathrm{N}$ and $\mathrm{C}$ transformations with different inputs. The field experiment linked these processes to seasonal and cumulative soil $\mathrm{N}$ dynamics and crop production, and long-term SOM stabilization. Assessment of the trade-offs between nutrient availability and stabilization in the short- to long-term revealed there was a temporary effect of residue quality on $\mathrm{N}$ and SOM dynamics. However, the examination of long-term SOM stabilization revealed no effect of residue quality or combination of organic resources with fertilizer.

In the short-term, residue quality modified the pattern of $\mathrm{N}$ availability. Tithonia had greater residue$\mathrm{N}$ mineralization than maize after 3 months in the
Table 2 The effect of different quality residues $(1.2 \mathrm{Mg}$ $\mathrm{C} \mathrm{ha}^{-1}$ ) with and without $\mathrm{N}$ fertilizer (120 kg N ha $\left.{ }^{-1}\right)$ during the long rains growing season on maize grain $\mathrm{N}$ content in 2007, grain yield in 2007, and mean yields from 2002-2006 (data adapted from Gentile et al. 2009; Chivenge et al. 2009)

Interactive effects were significant at $P<0.10^{*}$, $P<0.05^{* *}$, or not significant (ns)

\begin{tabular}{lclc}
\hline Treatment & $\begin{array}{l}2007 \text { grain N } \\
\left(\mathrm{kg} \mathrm{N} \mathrm{ha}^{-1}\right)\end{array}$ & $\begin{array}{l}2007 \text { grain yield } \\
\left(\mathrm{Mg} \mathrm{ha}^{-1}\right)\end{array}$ & $\begin{array}{l}2002-2006 \text { grain yield } \\
\left(\mathrm{Mg} \mathrm{ha}^{-1}\right)\end{array}$ \\
\hline Control & 33.6 & 2.19 & 2.05 \\
Control + fertilizer & 58.1 & 3.68 & 3.49 \\
Maize & 34.7 & 2.44 & 2.59 \\
Maize + fertilizer & 68.7 & 4.31 & 4.34 \\
Tithonia & 52.6 & 3.40 & 3.34 \\
Tithonia + fertilizer & 75.2 & 4.41 & 3.97 \\
SED & 6.8 & 0.49 & 0.31 \\
SED & 0.40 & 0.18 \\
Interidue & 5.6 & & $0.50^{*}$ \\
Maize & & $0.38^{\mathrm{ns}}$ & $-0.74 *$ \\
Tithonia & $9.5^{*}$ & $-0.48^{* *}$ & \\
\hline
\end{tabular}




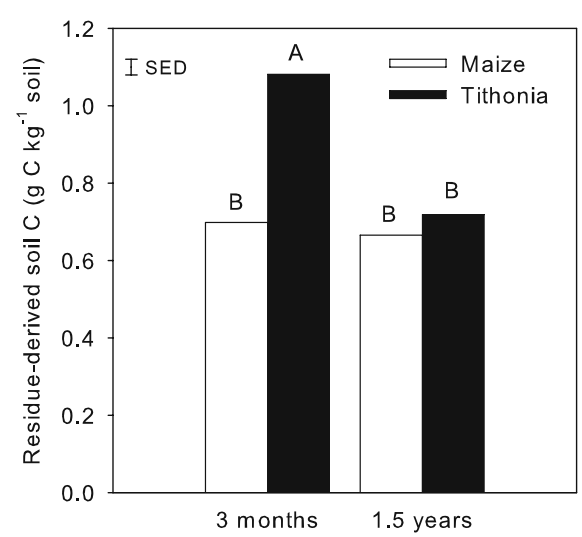

Fig. 4 Residue-derived $\mathrm{C}$ stabilized in the in the microcosm experiment after 3 months and $1.5 \mathrm{yr}$ incubation following application of different quality residues $\left(3.65 \mathrm{~g} \mathrm{C} \mathrm{kg}^{-1}\right.$ soil). Different letters indicate significant treatment differences at $P<0.05$

microcosm both in terms of total $\mathrm{N}$ concentrations and as a proportion of $\mathrm{N}$ applied (Fig. 1). This was also observed in the field during the 2007 long rains where tithonia led to early season net mineralization and increased mineral $\mathrm{N}$ levels at 29 DAP (Fig. 2). By definition, the high quality residue, tithonia, had a lower $\mathrm{C}: \mathrm{N}$ ratio than maize and thus a faster mineralization rate due to a greater supply of $\mathrm{N}$ for soil microorganisms (Heal et al. 1997). Previous studies have shown high quality residues with low $\mathrm{C}: \mathrm{N}$ ratios have greater residue- $\mathrm{N}$ mineralization than low quality residues (e.g., Constantinides and Fownes 1994; Sakala et al. 2000; Trinsoutrot et al. 2000; Vanlauwe et al. 2005). The timing of this residue-N mineralization can be critical and in the field trial, tithonia indeed released residue- $\mathrm{N}$ ahead of maximum crop $\mathrm{N}$ uptake at 66 DAP (Gentile et al. 2009). In an another field study, high quality Crotalaria juncea $\mathrm{L}$. residue exhibited early season mineralization but much of this $\mathrm{N}$ was leached down the soil profile prior to crop uptake (Mtambanengwe and Mapfumo 2006). Early season $\mathrm{N}$ availability in advance of crop demand increases the risk of $\mathrm{N}$ loss and is a major challenge for the use of high quality residues in environments prone to $\mathrm{N}$ leaching (Chikowo et al. 2006).

In addition to altering the timing of residue- $\mathrm{N}$ release, residue quality influenced $\mathrm{N}$ dynamics in combination with fertilizer. The microcosm experiment showed that the lower quality maize both immobilized more fertilizer- $\mathrm{N}$ and stimulated less residue-N mineralization than tithonia (Fig. 1). In fact, the balance of fertilizer-N immobilization versus stimulated residue- $\mathrm{N}$ release was in favor of $\mathrm{N}$ immobilization for maize and $\mathrm{N}$ mineralization for tithonia. Therefore, combining residue and fertilizer inputs created an interactive effect on mineral $\mathrm{N}$ availability that changed from negative to positive with increasing residue quality (Gentile et al. 2008a). Thus, combinations of low quality residue and fertilizer reduced the size of the mineral $\mathrm{N}$ pool while high quality residue and fertilizer increased the size of the mineral $\mathrm{N}$ pool compared to what would be expected from either input alone. Similar interactions between residue quality and fertilizer on $\mathrm{N}$ availability were observed in the field trial. Combining fertilizer with the low quality residue resulted in a net $\mathrm{N}$ immobilization and reduced the size of the available $\mathrm{N}$ pool, whereas combining fertilizer with the high quality residue did not change $\mathrm{N}$ availability relative to the fertilized control (Fig. 2).

While combining maize residue with fertilizer decreased mineral $\mathrm{N}$ in the upper soil profile during the 2007 growing season, it did not reduce crop yield (Table 2). We postulate that this inconsistency between available mineral $\mathrm{N}$ and crop $\mathrm{N}$ uptake is due to $\mathrm{N}$ leaching losses. Following the soil sampling at 49 DAP the second fertilizer dose was applied and the site received its largest rainfall event of the season, which likely leached much of the available mineral $\mathrm{N}$ in the root zone to the subsoil (Gentile et al. 2009). Indeed, mineral $\mathrm{N}$ levels in the subsoil during the 2007 field season clearly show greater $\mathrm{N}$ losses from the top $60 \mathrm{~cm}$ from the fertilizer and

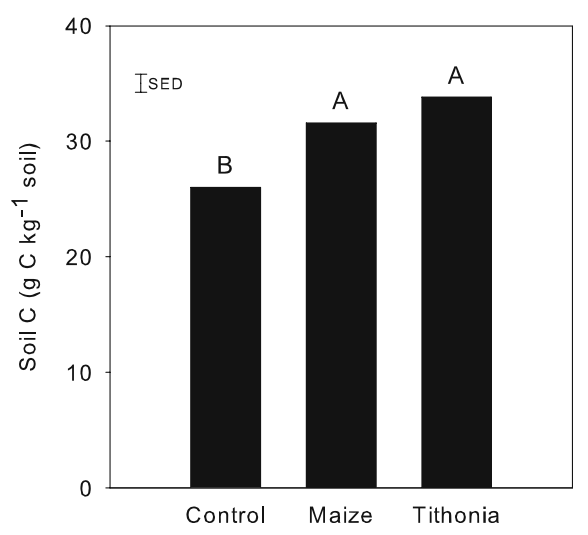

Fig. 5 Soil organic carbon in the field trial following three applications of different quality residues $\left(4 \mathrm{MgC} \mathrm{ha}^{-1} \mathrm{yr}^{-1}\right)$. Different letters indicate significant treatment differences at $P<$ 0.05 (data adapted from Gentile et al. 2008b) 
tithonia + fertilizer treatments than the maize + fertilizer treatment (Fig. 3). These concentrations include an accumulated loss from the previous growing seasons, but indicate high fluxes of $\mathrm{N}$ to the subsoil in the fertilizer and tithonia + fertilizer treatments. Combining fertilizer with maize showed a reduction in subsoil mineral $\mathrm{N}$ of nearly $200 \mathrm{~kg} \mathrm{~N} \mathrm{ha}^{-1}$. Similarly, in a lysimeter study, Vanlauwe et al. (2002) observed a reduction in $\mathrm{N}$ leaching when fertilizer was combined with low quality maize residue but not with high quality $M$. pruriens. Therefore, low quality residues can be used in combination with fertilizer to reduce $\mathrm{N}$ leaching and nutrient losses to the environment.

As residue quality clearly altered short-term $\mathrm{N}$ availability when combined with fertilizer, it also affected the interactive effect of combining inputs on crop production. Since equivalent rates of $\mathrm{N}$ were not applied across all treatments, the interactive effect indicates whether the combination treatment increased (positive effect) or decreased (negative effect) crop yield and $\mathrm{N}$ uptake relative to what was expected from the effect of either input alone. Increasing residue quality shifted the interactive effect of combining residue with fertilizer from positive to negative for crop $\mathrm{N}$ uptake and yield (Table 2). Combining tithonia with fertilizer decreased grain N content, 2007 yield, and 2002-2006 yields as compared to the sum of the effects of either input alone. In contrast, adding fertilizer with maize residue showed a trend for increased grain $\mathrm{N}$ uptake and 2002-2006 yields. These findings support our hypothesis that low quality residues would increase the interactive benefits of combining fertilizer and residue inputs. In a Zimbabwean trial, Mtambanengwe et al. (2006) also found that interactive effects on yield were negative with high quality $C$. juncea residue but were zero or positive with maize. The trend for positive interactive effects on yield with maize residue can probably be contributed to lower $\mathrm{N}$ leaching losses. The initial immobilization of fertilizer-N by the low quality residue protected this available $\mathrm{N}$ from losses prior to the peak period of crop demand. A greater retention of $\mathrm{N}$ in the root zone, combined with subsequent stimulation of residue- $\mathrm{N}$ mineralization, as observed in the microcosm experiment, could have increased $\mathrm{N}$ available for crop uptake in the combined treatment. The high input rates used in this field trial may have exceeded crop $\mathrm{N}$ requirements, especially in the tithonia + fertilizer treatment and contributed to the negative interactive effects on yield
(Chivenge et al. 2009). Input rates aside, the early season residue mineralization and lack of fertilizer immobilization shown by tithonia led to greater $\mathrm{N}$ availability ahead of crop demand. Therefore, it is likely that combining fertilizer with high quality residue will increase potential $\mathrm{N}$ losses and not produce beneficial interactive effects on yield.

While residue quality manipulated short-term $\mathrm{N}$ dynamics, it did not influence longer-term SOM stabilization. In the microcosm experiment, the greater mineralization rate of the tithonia residue increased the amount of residue-derived $\mathrm{C}$ recovered in the soil after 3 months (Fig. 4). However after $1.5 \mathrm{yr}$ of incubation, equivalent amounts of residuederived $\mathrm{C}$ were stabilized in the soil regardless of residue quality. These findings from the microcosm experiment were further supported by measures of soil organic $\mathrm{C}$ after $3 \mathrm{yr}$ of annual residue application in the field trial (Fig. 5). Even within more sensitive soil aggregate fractions, residue quality did not alter $\mathrm{C}$ contents (Gentile et al. 2008b). The addition of residues increased soil organic $\mathrm{C}$ over the control, but contrary to our hypothesis, it was by equivalent amounts regardless of quality. Similarly, field studies in other tropical and temperate regions with repeated applications of equivalent rates of different quality residues have shown no differences in long-term soil organic C contents (Larson et al. 1972; Nziguheba et al. 2005). Using ${ }^{13} \mathrm{C}$-enriched inputs, Voroney et al. (1989) found the same amount of input-derived C stabilized after $10 \mathrm{yr}$ following equivalent $\mathrm{C}$ applications of glucose versus wheat residue, clearly two inputs with drastically different qualities. The application of $\mathrm{N}$ fertilizer had no influence on $\mathrm{C}$ stabilization in the microcosm or field trial, which further supports that increased $\mathrm{N}$ availability, via mineral fertilizer or greater residue $\mathrm{N}$ concentrations, does not affect long-term SOM stabilization.

The combined results of the presented experiments indicate that residue quality and $\mathrm{N}$ fertilizer applications can be manipulated to influence short- but not long-term nutrient dynamics and stabilization. Therefore, managing inputs for ISFM should focus on optimizing short-term interactive effects to enhance $\mathrm{N}$ use efficiency. Medium to low quality residues, which are more widely available (Vanlauwe and Giller 2006), should be incorporated with mineral $\mathrm{N}$ fertilizer to generate beneficial interactive effects on yield and avoid leaching losses; whereas high quality 
residues, when available, should be directly incorporated. The addition of residue, whichever approach is taken, will promote SOM and improve long-term fertility. This study provides experimental support for a residue management decision tree developed by Palm et al. (2001), which recommends that residues be directly incorporated, combined with fertilizer, or surface applied according to classifications of decreasing quality. Further research is needed to evaluate input rates of residue and fertilizer combinations at levels more relevant for smallholder farmers in the region. The main mechanism behind the beneficial interactive effects on yield generated by combining low quality residue and fertilizer appears to be a reduction in $\mathrm{N}$ leaching and $\mathrm{N}$ loss prior to crop $\mathrm{N}$ demand. Therefore, this practice may be best suited to environmental conditions prone to $\mathrm{N}$ leaching losses, such as high early season rainfall or coarse textured soils.

Acknowledgements We thank H. Wangechi, W. Ngului and technical staff at TSBF-CIAT Nairobi for maintenance of the field trial. This research was supported by the National Science Foundation (DEB: 0344971).

Open Access This article is distributed under the terms of the Creative Commons Attribution Noncommercial License which permits any noncommercial use, distribution, and reproduction in any medium, provided the original author(s) and source are credited.

\section{References}

Bird JA, van Kessel C, Horwath WR (2003) Stabilization of ${ }^{13} \mathrm{C}$-carbon and immobilization of ${ }^{15} \mathrm{~N}$-nitrogen from rice straw in humic fractions. Soil Sci Soc Am J 67:806-816

Chikowo R, Mapfumo P, Leffelaar PA, Giller KE (2006) Integrating legumes to improve $\mathrm{N}$ cycling on smallholder farms in sub-humid Zimbabwe: resource quality, biophysical and environmental limitations. Nutr Cycl Agroecosyst 76:219-231

Chivenge P, Vanlauwe B, Gentile R, Wangechi H, Mugendi D, van Kessel C, Six J (2009) Organic and mineral input management to enhance crop productivity in Central Kenya. Agron J 101:1266-1275

Constantinides M, Fownes JH (1994) Nitrogen mineralization from leaves and litter of tropical plants: relationship to nitrogen, lignin and soluble polyphenol concentrations. Soil Biol Biochem 26:49-55

Doane TA, Horwath WR (2003) Spectrophotometric determination of nitrate with a single reagent. Anal Lett 36:27132722

FAO (1998) World reference base for soil resources. FAO, Rome
Forster JC (1995) Soil nitrogen. In: Alef K, Nannipieri P (eds) Methods in applied soil microbiology and biochemistry. Academic, San Diego, pp 79-87

Gentile R, Vanlauwe B, Chivenge P, Six J (2008a) Interactive effects from combining fertilizer and organic residue inputs on nitrogen transformations. Soil Biol Biochem 40:2375-2384

Gentile R, Vanlauwe B, Kavoo A, Chivenge P, Six J (2008b) Residue quality and $\mathrm{N}$ fertilizer do not influence aggregate stabilization of $\mathrm{C}$ and $\mathrm{N}$ in two Kenyan soils. Nutr $\mathrm{Cycl}$ Agroecosyst. doi:10.1007/s10705-008-9216-9

Gentile R, Vanlauwe B, van Kessel C, Six J (2009) Managing $\mathrm{N}$ availability and losses by combining fertilizer-N with different quality residues in Kenya. Agric Ecosyst Environ 131:308-314

Gleixner G, Poirier N, Bol R, Balesdent J (2002) Molecular dynamics of organic matter in a cultivated soil. Org Geochem 33:357-366

Harris RF, Allen ON, Chesters G, Attoe OJ (1963) Evaluation of microbial activity in soil aggregate stabilization and degradation by the use of artificial aggregates. Soil Sci Soc Am Proc 27:542-545

Heal OW, Anderson JM, Swift MJ (1997) Plant litter quality and decomposition: an historical overview. In: Cadisch G, Giller KE (eds) Driven by nature: plant litter quality and decomposition. CAB International, Wallingford, pp 3-30

Jama B, Palm CA, Buresh RJ, Niang A, Gachengo C, Nziguheba G, Amadalo B (2000) Tithonia diversifolia as a green manure for soil fertility improvement in western Kenya: a review. Agroforest Syst 49:201-221

Kiem R, Kögel-Knabner I (2003) Contribution of lignin and polysaccharides to the refractory carbon pool in Cdepleted arable soils. Soil Biol Biochem 35:101-118

Larson WE, Clapp CE, Pierre WH, Morachan YB (1972) Effects of increasing amounts of organic residues on continuous corn: II. Organic carbon, nitrogen, phosphorus, and sulfur. Agron J 64:204-208

Marschner B, Brodowski S, Dreves A, Gleixner G, Gude A, Grootes PM, Hamer U, Heim A, Jandl G, Ji R, Kaiser K, Kalbitz K, Kramer C, Leinweber P, Rethemeyer J, Schäffer A, Schmidt MWI, Schwark L, Wiesenberg GLB (2008) How relevant is recalcitrance for the stabilization of organic matter in soils? J Plant Nutr Soil Sci 171:91110

Melillo JM, Aber JD, Muratore JF (1982) Nitrogen and lignin control of hardwood litter decomposition dynamics. Ecology 63:621-626

Mtambanengwe F, Mapfumo P (2006) Effects of organic resource quality on soil profile $\mathrm{N}$ dynamics and maize yields on sandy soils in Zimbabwe. Plant Soil 281:173191

Mtambanengwe F, Mapfumo P, Vanlauwe B (2006) Comparative short-term effects of different quality organic resources on maize productivity under two different environments in Zimbabwe. Nutr Cycl Agroecosyst 76:271-284

Mugendi DN, Kanyi M, Kung'u JB, Wamicha W, Mugwe JN (2003) The role of agroforestry trees in intercepting leached nitrogen in the agricultural systems of the central highlands of Kenya. East Afr Agric For J 69:69-79 
Mummey D, Holben W, Six J, Stahl P (2006) Spatial stratification of soil bacterial populations in aggregates of diverse soils. Microb Ecol 51:404-411

Myers RJK, Palm CA, Cuevas E, Gunatilleke IUN, Brossard M (1994) The synchronisation of nutrient mineralisation and plant nutrient demand. In: Woomer PL, Swift MJ (eds) The biological management of tropical soil fertility. John Wiley \& Sons, Chichester, pp 81-116

Nziguheba G, Merckx R, Palm CA (2005) Carbon and nitrogen dynamics in a phosphorus-deficient soil amended with organic residues and fertilizers in western Kenya. Biol Fertil Soils 41:240-248

Palm CA, Gachengo CN, Delve RJ, Cadisch G, Giller KE (2001) Organic inputs for soil fertility management in tropical agroecosystems: application of an organic resource database. Agric Ecosyst Environ 83:27-42

Palm CA, Sanchez PA (1991) Nitrogen release from the leaves of some tropical legumes as affected by their lignin and polyphenolic contents. Soil Biol Biochem 23:83-88

Parton W, Silver WL, Burke IC, Grassens L, Harmon ME, Currie WS, King JY, Adair EC, Brandt LA, Hart SC, Fasth B (2007) Global-scale similarities in nitrogen release patterns during long-term decomposition. Science 315: 361-364

Sakala WD, Cadisch G, Giller KE (2000) Interactions betwen residues of maize and pigeonpea and mineral $\mathrm{N}$ fertilizers during decomposition and $\mathrm{N}$ mineralization. Soil Biol Biochem 32:679-688

Sanchez PA, Jama B (2002) Soil fertility replenishment takes off in East and Southern Africa. In: Vanlauwe B, Diels J, Sanginga N, Merckx R (eds) Integrated plant nutrient management in sub-Saharan Africa: from concept to practice. CABI, Wallingford, pp 23-46

Six J, Carpentier A, van Kessel C, Merckx R, Harris D, Horwath WR, Luscher A (2001) Impact of elevated $\mathrm{CO}_{2}$ on soil organic matter dynamics as related to changes in aggregate turnover and residue quality. Plant Soil 234:2736

Six J, Conant RT, Paul EA, Paustian K (2002) Stabilization mechanisms of soil organic matter: implications for Csaturation of soils. Plant Soil 241:155-176

Stark JM, Hart SC (1996) Diffusion technique for preparing salt solutions, Kjeldahl digests, and persulfate digests for nitrogen-15 analysis. Soil Sci Soc Am J 60:1846-1855
Tisdall JM, Oades JM (1982) Organic matter and water-stable aggregates in soils. J Soil Sci 33:141-163

Trinsoutrot I, Recous S, Bentz $B$, Linères $M$, Chèneby $D$, Nicolardot B (2000) Biochemical quality of crop residues and carbon and nitrogen mineralization kinetics under nonlimiting nitrogen conditions. Soil Sci Soc Am J 64:918-926

Vanlauwe B, Aihou K, Aman S, Iwuafor ENO, Tossah BK, Diels J, Sanginga N, Lyasse O, Merckx R, Deckers J (2001a) Maize yield as affected by organic inputs and urea in the West African moist savanna. Agron J 93:1191-1199

Vanlauwe B, Bationo A, Chianu J, Giller KE, Merckx R, Mokwunye U, Ohiokpehai O, Pypers P, Tabo R, Shepherd K, Smaling E, Woomer PL, Sanginga N (2009) Integrated soil fertility management: Operational definition and consequences for implementation and dissemination. Outlook on Agriculture In Press.

Vanlauwe B, Diels J, Aihou K, Iwuafor ENO, Lyasse O, Sanginga N, Merckx R (2002) Direct interactions between $\mathrm{N}$ fertilizer and organic matter: evidence from trials with ${ }^{15} \mathrm{~N}$-labelled fertilizer. In: Vanlauwe B, Diels J, Sanginga $\mathrm{N}$, Merckx R (eds) Integrated plant nutrient management in Sub-Saharan Africa: from concept to practice. CAB International, New York, pp 173-184

Vanlauwe B, Gachengo C, Shepherd K, Barrios E, Cadisch G, Palm CA (2005) Laboratory validation of a resource quality-based conceptual framework for organic matter management. Soil Sci Soc Am J 69:1135-1145

Vanlauwe B, Giller KE (2006) Popular myths around soil fertility management in sub-Saharan Africa. Agric Ecosyst Environ 116:34-46

Vanlauwe B, Wendt J, Diels J (2001b) Combined application of organic matter and fertilizer. In: Tian G, Ishida F, Keatinge JDH (eds) Sustaining soil fertility in West Africa. Soil Science Society of America and American Society of Agronomy, Madison, pp 247-279

von Lützow M, Kögel-Knabner I, Ekschmitt K, Matzner E, Guggenberger G, Marschner B, Flessa H (2006) Stabilization of organic matter in temperate soils: mechanisms and their relevance under different soil conditions- a review. Eur J Soil Sci 57:426-445

Voroney RP, Paul EA, Anderson DW (1989) Decomposition of wheat straw and stabilization of microbial products. Can J Soil Sci 69:63-77 